\title{
O Contratualismo - Posição de Rousseau e Kant
}

Miguel Reale

O contratualismo, a explicação da ordem jurídica como simples resultado de um encontro de vontades, constitue, ainda hoje, um tema inexgotado e, sob vários aspetos, uma questão aberta, tais e tantas são as divergências entre os mais sagazes intérpretes do pensamento de Altusio, Grócio e seus continuadores.

Não conheço, e penso mesmo que ainda não foi escrita, uma obra, que nos ofereça das varias teorias contratuais uma síntese poderosa e, ao mesmo tempo, viva, pela riqueza dos particulares e a justa compreensão de cada autor em face de seu tempo e no conjunto do processo histórico.

Um trabalho dessa natureza está nos fazendo grande falta para compreensão melhor do movimento ideológicosentimental que constituiu uma das tendências fundamentais daquela que, pomposamente, se denominou "cultura moderna".

Realmente, impóssivel seria penetrar na essência do pensamento juridico post-renascentista sem a análise aprofundada do contratualismo, cujas raizes se prolongam até ao mundo helênico (1), mas que só chegou a representar a

(1) Como já foi posta em dúvida esta minha afirmação, aliás banal para os conhecedores de História da Filosofia do Direito, lembro aqui estas máximas de EPICURo: “A justiça não tem existência por si, mas existe sempre nas relações recíprocas, onde quer que haja um pacto de não se fazer e de não se sofrer dano. Entre os animais, que não puderam estipular contratos para não fazer nem sofrer danos, não se verifica o justo ou o injusto; e assim tambem entre os povos que não quizeram realizar acôrdos para não se 
nota dominante das concepções jurídico-políticas depois da Idade Média, desde quando se procurou explicar a sociedade em razão do indivíduo e, especialmente, em razão de sua vontade.

De tal ordem é a preeminência dessa doutrina, que não será exagêro dizer que a história do contratualismo é a história mesma da cultura jurídica individualista burgueza. Representando, de início, uma simples justificação, muitas vezes implícita, da origem e da autoridade do Govêrno (pactum subjectionis), a idéia do contrato social veiu se transformando, aos poucos, na explicação originária da própria sociedade e do Estado (pactum unionis civilis), à medida que o individualismo se afirmava como tendência peculiar da época. Ao mesmo tempo, esse potenciamento da doutrina exigia explicações mais refinadas e sutís, de sorte que o primitivo contratualismo, que repousava sôbre a crença na historicidade do "estado de natureza" (contratualismo de carater histórico, que ainda é o de Grócıo e de LOGKE) se converteu em uma explicação racional da ordem jurídica sôbre um pressuposto de ordem psicológica (contratualismo como pressuposto psicológico, tal como nô-lo apresentam HobBes e Roussead), para, afinal, sublimar-se em um méro pressuposto lógico, em uma ficção racionalista (contratuatismo de ordem lógica, de KANT e Fichte).

Com isto, ao sabor dos acontecimentos, segundo múltiplas e contraditórias conjunturas políticas, religiosas e econômicas, o contratualismo veiu assumindo sentidos diversos, ora pessimista sôbre a natureza humana nas conclusões estatalistas de HoBBes, contemporâneo dos Stuarts autoritários, ora otimista quanto aos indivíduos, mas desconfiado do poder dos Govêrnos na obra de Locke, contemportâneo de Guilherme de Orange, o primeiro monarca constitucional... E, assim, cinco séculos seguidos, ao influxo das mutações da história moderna, mal podemos acompanhar essa aventura e desaventura de um conceito.

prejudicar. O direito segundo a natureza é sinal da utilidade de não se fazer nem receber dano". Cfr. Massime Capitali, 31, 32, 38, trad. BIGNONE. 
Nem se diga que Kant e Fichte concluem a curiosa e irregular trajetória. O século XIX, à primeira vista tão infenso ao contratualismo, não o abandona de todo, pois, se repele as suas premissas por ilógicas, não quer se separar das últimas conclusões que delas resultaram. Como foi bem observado por JellineK, todo o Estado Moderno foi influenciado pela teoria contratualista da maneira mais profunda. As sentenças fundamentais dos partidos liberais, políticas e econômicas, foram elaboradas sob a sua inspiração, mas não deixaram de ser, depois, paradoxalmente defendidas pelos mais apaixonados destruidores das premissas contratuais...

Não é só. A própria idéia ressurgiu sob roupagens novas, atuando no bojo de teorias que lhe pareciam ser de todo em todo contrárias. Em minha tese sôbre os "Fundamentos do Direito", penso ter mostrado as inegáveis ligações existentes entre o contratualismo e a Escola Histórica de SAvigny, notando a atualidade do néo-contratualismo de Bierling. Fiz ver o caráter especialíssimo da doutrina da crescente contratualização da sociedade exposta por SumNer Maine e Spencer, a qual transfere o contrato, do início para o fim da vida social, de sorte que aquilo que, antes, era fonte de juridicidade passa a ser termo final do processo evolutivo (contratualismo "in fieri", de processo) (2).

Eis ai algumas notas perfunctórias, porém, bastantes para nos convencer da ousadia de quantos vêm no contratualismo um simples "equívoco" felizmente desfeito, um máu sonho de filósofos esquecidos das verdades elementares que condicionam todo fenômeno de convivência. $O$ curioso é que aqueles que mais desdém manifestam pelo estudo das teorias contratualistas são, em geral, os que mais se mantêm fieis às conclusões das esquecidas premissas..

A que se deverá atribuir essa desconfiança contra o contratualismo, especialmente por parte de "contratualistas que se ignoram", a ponto de não o estudar com carinho

(2) Cfr. Miguel Reale - Fundamentos do Direito - São Paulo, 1940, pg. 9 e segs. e 49 e segs. 
e simpatia? A pergunta é cheia de indagações e de motivos profundos.

Terá sido causa da sub-estima de tão grande tema a feição paradoxal e quasi mitológica do contratualismo na obra de Rousseau, - vítima, aliás, de interpretações superficiais e, não raro, tendenciosas - ou, mais genericamente, a aversão preconcebida por todos os trabalhos da chamada Escola do Direito Natural, condenada com tanto mais veemência quanto mais era ignorada? Ou devemos buscar, antes, a causa dessa inadvertência na própria pequenez da especulação filosófico-jurídica da época do primado dos "técnicos do Direito" e dos pretensos redutores da Filosofia Jurídica a um conjunto de dados sociológicos?

E' por esses motivos e, tambem, porque de certas teorias não temos conciência enquanto vivemos sob a sua influência, com a mesma atitude espiritual que as tornou possiveis. Hoje que o individualismo não constitue a nota dominante do mundo jurídico, quando somos, quasi que por índole, contrários a toda explicação da sociedade apenas "a parte subjecti", estamos em melhores condições de compreender o contratualismo, a teoria característica de uma forma de cultura que, embora confusamente, já sentimos não ser mais a nossa. Para exato julgamento dos grandes assuntos relativos ao destino do homem e da sociedade é necessário isto: entrar neles para os compreender com simpatia, e sair deles para dominá-los.

Ninguem sente mais a necessidade de refutar a teoria contratualista do ponto de vista histórico e sociológico, sendo, porém, já tempo de reconhecer que, dentro đo sistema cultural burguez e individualista, ela representou a mais. importante e "natural" justificação do Estado. Posta a exigência de explicar o fenômeno estatal sob o ângulo visual do indivíduo, era lógico que se recorresse, como caminho mais plano, à idéia de que o Estado é méro resultado de um encontro de vontades individuais. Demonstrado que a sociedade política resultara de um ato dos próprios individuos, concientes da necessidade da ordenação comum, 
resolvido ficava o problema da obediência às leis, com a redução do problema do fundamento da autoridade ao da "auto-obrigação dos governados" (3).

Dava-se, dess'arte, conforme às tendências fundamentais da cultura burgueza, solução a um dos problemas primordiais e apaixonantes da Filosofia Jurídica, que é o da relação entre autoridade e liberdade, concretizado no mais particular de saber como se justifica o poder de fazer as leis e se impõe o correspondente dever de obedecê-las.

Visando explicar a relação "autoridade-liberdade", que, à primeira vista, parece redundar em uma antinomia, comparavel, na tela limitada do Direito, àquela que aparentemente se põe, na Filosofia Geral, entre sujeito e objeto, ou, se quizerem, entre "eu" e "não-eu" — os pensadores da "cultura moderna" apegaram-se à idéia de um contrato originário, variando as suas condições e consequências segundo os fins que tinham em mira, em função de variáveis exigências históricas. Isto é, de certa forma, explicavel quando se pensa que as doutrinas filosófico-jurídicas não são quadros separaveis do sistema cultural em que floresceram, não são meros paineis que valham por si mesmos, por conterem, no conjunto harmônico de suas linhas e côres, a “sua" realidade total, mas são, antes, expressões de vida, cujo valor se afere pela sua consonância ou correspondência com os fatos, visto serem sempre - referimo-nos, é claro, às concepções jurídicas que, como complexos de

(3) "Para a Escola do Direito Natural, nota Gustav Radbruch, o contrato era, como se sabe, o fundamento de todo o Direito, fornecendo a solução do problema básico da Filosofia Jurídica individualista - isto é, o problema de saber como é possivel que o Direito, que foi inventado para servir exclusivamente os individuos, póde tambem obrigá-los e vinculá-los ao mesmo tempo. 'Fundar o Estado, com todo o seu poder jurídico soberano, sôbre a idéia dum contrato celebrado entre os seus membros, pareceu ser o suficiente para poder apresentar, em última análise, toda obrigação como uma auto-obrigação. Julgou-se encontrar, assim, na idéia de contrato social o meio que permitia reconduzir com pleno exito toda a heteronomia a uma autonomia e, dêste modo, resolver todo o direito público no direito privado". Radbruch Filosofia do Direito, trad. de Cabral de Moncada, São Paulo, 1937, pg. 207. 
idéias-fôrça, atuam efetivamente no destino de um povo, visto serem sempre momentos de história, abstrações, cujo exato e rico significado não se revela ao estudioso que as não saiba situar segundo as coordenadas do espaço e do tempo.

Era natural, por conseguinte, que a tese contratualista - de cunho individualista sempre, por fazer resultar a autoridade do fictício querer harmônico dos obrigados - encontrasse o seu clima propício na época da ascensão do individuo, cujo interesse foi posto no ápice da vida da sociedade e do Estado, como sua medida e exclusiva razão de ser.

Se a concepção contratualista se harmoniza com as múltiplas tendências individualistas - e de HobBes já se disse que ele foi tão individualista que chegou, paradoxalmente, à negação do individuo como "pessoa" para salvaguardar e garantir a sua esfera de interesses - se o contratualismo se adatou, com espantosa flexibilidade, às contingências dos tempos, é justo reconhecer que foi na França do século XVIII e, mais especialmente, na obra de Rousseau, que a doutrina encontrou o seu filão mais fecundo e, por assim dizer, mais autêntico.

Rousseau representa o ponto extremo do contratualismo na sua função fundamental de instrumento de reforma dos maus govêrnos: depois dele, desde Kant e Fichte, a teoria perde a fôrça propulsora, para desempenhar mais a missão lógico-explicativa da essência das sociedades bem governadas.

Na pena de Rousseau, o "contrato social" é uma idéia, que não se põ̉e como pressuposto lógico de filósofo, mas como arma de reformador político. Daí a necessidade que ele sente de argumentar dando visos de historicidade ao que é apenas conjetural, pintando o "estado natural" primevo e o "contrato social" segundo o que psicologicamente estava mais de acôrdo com as aspirações e as necessidades 
coletivas de sua época. Daí tambem o êrro em que incidiram quantos lhe atribuiram a infantilidade de pretender reconstituir, como historiador tresloucado, os primórdios da convivência humana.

Felizmente para Rousseau e a cultura, já vái longe o tempo em que se indagava, em impagavel desafio, em que tabelião se firmára o célebre contrato...

Nada é, com efeito, tão ingênuo como atribuir ao pensador genebrino a ingenuidade de acreditar na origem contratual da sociedade. Assim como não se desconhece a poderosa fôrça pragmática que a noção de "contrato social" assume no pensamento de Rousseav, como meio eficiente de que ele lança mão para revelar os vícios do "Ancien Regime" pelo contraste com uma ordem jurídica idealizada, assim tambem é preciso convir que ele próprio não dá carater histórico à sua teoria (4).

Nêsses pontos pode-se dizer que reina acôrdo entre os mais concienciosos intérpretes de suas obras. As divergências hoje em dia versam sôbre questões mais sutís, concernentes ao exato valor dado ao "contrato social", confessadamente aceito como hipótese ou conjetura.

Segundo alguns autores, como Stammler, Renouvier, Liepmann, Haymann e Del Vecchio, (5) o contrato é, na doutrina de Rousseau, uma simples "hipótese explicativa",

(4) E' o que vemos claramente afirmado logo no início de seus Discours sur l'origine et les fondements de l'inégalité parmi les hommes, onde se encontra esta advertência, infelizmente só muito tarde atendida: "Commençons donc par écarter tous les faits, car ils ne touchent point à la question. Il ne faut pas prendre les recherches dans lesquelles on peut entrer sur ce sujet pour des verités historiques, mais seulement pour des raisonnements hypothetiques et conditionnels, plus propres à eclaircir la nature des choses qu'à en montrer la veritable origine, et semblables d̀ ceux qui font tous les jours nos physiciens sur la formation du monde". (Oeuvres complétes, Paris, 1826, tomo I, pg. 36).

(5) Cfr. Stammler, Economia y Derecho, trad. de W. Roces, Madrid, 1929, pg. 153 e segs.; Jellineck, La dottrina dello Stato, trad. de M. Petrozziello, Milão, 1921, pg. 417; Renouvier, Science de la Morale, Alcan, I, pg. 325 e segs.: DEL Vecchio,'Su la teoria del contratto Sociale, 1906; Solari, Individualismo $e$ diritto privato, Vol, I da Filosofia del Diritto Privato, Turim, 1939, pg. 111 e segs. e Miguel Reale, Fundamentos do Direito, cit. pg. 7 e segs.. 
de puro valor racional e lógico, sem nenhum significado empírico, não constituindo nem uma realidade histórica (fato sôbre o qual, como dissemos, não há mais divergência) nem mesmo uma realidade psicológica.

Outros autores, e entre eles se destacam HöFfding e Solari, concordam com a falta de "historicidade" na construção contratualista de JEAN JACQUES, mas contestam que a sua explicação seja puramente racional e lógica. Se RousSEAU, dizem eles, não acreditava ingenuamente na origem da sociedade mediante um contrato, por outro lado, nunca pôs em dúvida a verdade e a realidade psicológica de sua concepção. Para ele os homens, no estado de natureza, não poderiam ser senão como ele os concebia e, o seu "homem natural", longe de ser um produto da fantasia, sintetizava, a seu ver, da maneira mais perfeita, as tendências essenciais e puras da natureza humana.

Dentre os partidários da primeira interpretação talvez seja DeL Vecchio o mais extremado. Não obstante algumas restrições, atendendo ao temperamento emotivo de RoussEaU e ao grande papel que o sentimento representa em sua vida e em sua obra, o mestre peninsular nos apresenta o criador da "Nouvelle Héloïse" como um kantista "avant la lettre". E' verdade, observa Del Vecchio, que o "Contrato Social" é uma obra que, pela sua estrutura extrínseca e por certos modos de dizer particulares, se insere, de um modo coerente, na escola do jus naturae; mas essa afinidade com a "mitologia pseudo-histórica do passado ideal" é bem mais aparente do que real.

“A representação mítica de um estado originário de liberdade e de igualdade, escreve o antigo catedrático de Roma, serve a Rousseau tão somente como meio para afirmar a validade absoluta dos principios que lhe eram sugeridos, fóra de toda e qualquer observação ou noção histórica, pela voz categórica da conciência" (sic) (6).

(6) Cfr. Del Vecchio, Justice-Droit-État, Paris, 1938, pg. 259 e, em geral, todo o ensaio intitulado "Des caractères fondamentaux de la philosophie politique de Rousseav". - o grifo no texto é nosso. 
Com semelhante interpretação, porém, o contrato rousseauniano perde a sua fôrça de doutrina política assente em dados emotivos indispensaveis à exigida revisão do fato social, para se esfriar, permitam-nos o termo, em uma concepção explicativa, "post factum", como se entre o "Contrato Social" de Rousseau e a "Doutrina do Direito" de Kant não se tivesse verificado o advento do grande fato, a Revolução Francesa, que o primeiro contribuiu a preparar e o segundo tentou compreender em seu significado universal.

Um escreve sôbre o Direito e o Estado antes; o outro, depois da Revolução: uma doutrina sucede à outra, não resta dúvida, desenvolvendo-se ambas no mesmo ciclo histórico, mas cada qual conserva um significado especial. Dirse-ia que a primeira é mais fôrça propulsora, mais pensamento em ação; a segunda é mais pensamento concentrado em si mesmo, como que posto acima do fato, dominada a ação pela análise serena e objetiva dos imperativos racionais.

Rousseau prepara e antecipa, sob certos aspectos, a KaNT, mas entre a teoria jurídico-política de um e a do outro ha uma experiência curta, violenta e decisiva, que os olhos já cansados do crítico insuperavel acompanharam, cheios de entusiasmo e de apreensão, tentando, à luz do que lhe parecia universal segundo os ditames de sua ética, penetrar nas linhas do novo equilíbrio contido no âmago do fato revolucionário. (7).

Apresentarmos o contratualismo de Rousseau como uma concepção puramente lógica-explicativa é, pois, cousa que equivale a fazer um salto na história. Apriorista, hipoté-

(7) De fato, como observa Cassirer, se Kant hauriu em RousSEAU a expressão teórica (theoretischen ausdruck) de seu pensamento político, a sua visivel eficácia prática (ihre sichtbare praktische Wirksamkeit): ele a encontrou na Revolução Francesa, na qual via a promessa da realização de um puro direito racional. (Er sieht in der französischen Revolution die Verheiszung der Verwirklichung des reinen Vernunftrechts). Cfr. ERNST CASSIRRR Kants Leben und Lehre, Berlim, 1921, pg. 398. Escrevendo em 1793, KANT não podia deixar de interpretar a "teoria" de Rousseau, sem levar em conta a "prática" revolucionária. 
tico, conjetural, é, por certo, o contratualismo rousseauniano, mas tais afirmações não autorizam a afirmar, como faz Del Vecchio, que para Rousseau o contrato social é algo comparavel ao imperativo categorico de KANT, não recebendo a sua validade do assentimento tácito ou expresso dos obrigados, por ter uma validade objetiva e universal, que independe do fato puramente psicológico da conciência, simples meio da manifestação dêsse valor absoluto.

"Assim, conclue o ilustre jurista-filósofo, a máxima do contrato tem para Rousseau um sentido eminentemente regulativo ou deontológico: o contrato fornece o tipo universal da constituição política revelado pela razão como estando em harmonia com a essência do homem, e serve, por isso, de critério para apreciar as constituições existentes. As proposições jurídicas positivas são, relativamente aos princípios. fixados nessa máxima, o que são os objetos a medir para a unidade de medida". (8)

Como já tive ocasião de afirmar, tambem penso que o. contratualismo de Rousseau tem um sentido deontológico, mas tal conclusão não implica na transformação do pensador francês em um precursor do formalismo ético de KavT.

No fundo, é essa a opinião dos já citados Höfforng e Solari. Este ilustre mestre da Universidade de Turim, um. dos mais penetrantes pesquisadores da História da Filosofia do Direito, contesta essa pretensa antecipação do imperativo categórico de KaNT, mesmo porque para Rousseau a verdade, antes de ser conhecida pelo intelecto, é intuida pelo. sentimento.

"No meu modo de ver, observa Solari, o homem e o estado de natureza não são, no pensamento de Rousseau, nem hipóteses fantásticas, nem postulados lógicos. A retórica e a fantasia, a que Rousseau se abandona, referem-se mais à forma do que à substância da doutrina. Por outro lado, a aversão de Rousseau pela razão e as construções puramente metafisicas, o valor teorético e prático reconhecido ao sen-

(8) Cfr. Del Vecchio, Justice-Droit-Etat, cit., pg. 262 e segs.. 
timento, as contradições mesmas em que ele se debate são incompativeis com a interpretação lógica, formalística, unitária de seu pensamento, que não pode ser despido dos elementos empíricos em virtude dos quais adquire vida e significado histórico". (9)

Negando, embora, o carater lógico-formalístico do contratualismo de Rousseau, e afirmando "a verdade e a realidade psicológica de sua concepção", Solari não deixa de observar que o pensador genebrino é o primeiro a apresentá-la como uma conjetura e uma hipótese.

No mesmo sentido, mas de maior precisão, são as conclusões do eminente filósofo dinamarquês Harald HöffDing no belo ensaio dedicado ao autor de "Emilio".

Declara Höffding que Rousseau não teve a preocupação de conhecer uma fase histórica desaparecida, mas que, voltado para a observação de si mesmo, foi levado ao conceito psicológico da natureza. Abandonando a revelação e a história natural, ele mergulhou na contemplação do que se passa na alma humana afim de descobrir, dessa maneira, as potências e os instintos fundamentais do ser humano.

"Com isso, - declara o preclaro historiador da Filosofia Moderna - ele não visa se ocupar com uma era desaparecida; o que, antes, ele claramente percebe é que tal processo lhe permite alcançar o conhecimento de uma hipótese psicológica "mais apta a lançar luz sôbre a natureza das cousas do que a mostrar a sua verdadeira origem". As tendências fundamentais do ser humano se manifestam mais ou menos claramente em todos os tempos. Quando RousSEAU denomina estado natural o estado no qual essas tendências essenciais chegam à sua perfeita eclosão, ele quer, com esse termo, indicar, (como ele mesmo o diz), "un état qui n'existe plus, qui n'a pieut'être point existé, qui probablement n'existera jamais, et dont il est pourtant nécessaire d'avoir des notions justes pour bien juger de notre état pre-

(9) G. Solari, Filosofia del Diritto Privato, vol. I (IndividuaJismo e Diritto Privato), Turim, 1939, pgs. 111 e seg. 
sent" (Prefácio dos Discours sur TOrigine de l'Inégalité). Devemos, pois, nos servir de sua hipótese psicológica como de uma medida". (10).

De qualquer forma, quer se considere a idéia do contrato social na obra de Rousseau uma hipótese lógica ou uma hipótese psicológica, quer se interprete a sua concepção levando-se em conta os elementos de ordem afetiva, que me parecem dela inseparaveis, quer seja ela reduzida a méra criação apriorística da razão, o certo é que estamos sempre deante de uma hipótese e, o que cumpre notar, de uma hipótese valorativa, de uma médida de valores sociais e humanos. E esse significado deontológico dado ao contratualismo que coloca o nosso pensador em uma posição nova, de que Emanuel Kant soube depois se utilizar para a mais clara fundamentação do Direito da época individualista. (11).

Em suma, a concepção de Rousseau não póde ser apreciada no plano da pura criação lógica, nem a idéia do contrato social como hipótese explicativa deve ser considerada resultante de uma atitude inicial de crítica de nossa faculdade de conhecer.

(10) HöfFding, Jean Jacques Rousseau et sa philosophie, trad. de De. Coussange, Paris, 1912, pg. 110 e seg. Em nota, na pg. 111, - autor lembra, muito a propósito, que, mais tarde, Rousseau, em uma carta a USTERI, se queixou por não terem querido compreender que ele concebia o estado de natureza como uma hipótese e não como um estado real.

Mais adeante, Höfforng completa o seu pensamento, dizendo que para Rousseau é hipótese psicológica tanto o "estado de natureza" como o "contrato social". "Rousseau, diz ele, considera o estado de natureza e o contrato original mais como normas, aptas a nos fazer aquilatar da normalidade da evolução social, do que como fatos históricos" (pg. 155). Note-se como Höffrding caracteriza, admiravelmente, o valor deontologico da concepção rousseauneana, dominante mas não exclusivo, reconhecendo ainda a fundamentação mais psicológica do que lógica da hipótese contratual. Não se trata, com efeito, para RousseAu de uma hipótese fantástica, mas de uma conjetura assente no estudo da natureza humana.

(11) Observe-se, pelas passagens acima citadas, como tanto DEL VeCGHIo como HöfFDiNG consideram o contrato social uma "unidade de medida", uma norma de aferição de valores no plano da ordem jurídico-social. ' $E^{\prime}$ essa, na realidade, a inovação genial de Rousseau. 
Se Rousseau não crê nas ilimitadas possibilidades da razão, não descrê do conhecimento pelas vias mais imediatas do sentimento. O "estado de natureza" e o "contrato social", tal como ele os concebe, são expressões daquilo que, à luz pura do sentimento, lhe parece constituir a realidade humana e social autêntica, despida de todo o artifício forjado atravez de uma existência esquecida da espontaneidade natural.

Na época do mais impressionante desprezo pela história; no século em que Voltaire sorria, sarcasticamente, do passado, vendo nele apenas "les erreurs et les prejugés se succédre tour à tour et chasser la verité et la raison"; no momento em que as poderosas hipóteses cosmológicas, como a de Newton, enchiam os grandes espiritos de respeitosa admiração, nada de extranho que Rousseau - homem plenamente integrado no "climax" intelectual de seu tempo almejasse lançar uma grande hipótese explicativa nos dominios da Política e do Direito, condenando, ao mesmo tempo, como inúteis e prejudiciais, os fatos históricos, como se estes não fossem a condição primordial do acêrto da hipótese. (12)

Compreende-se, dess'arte, o motivo pelo qual, no citado trecho dos "Discursos sôbre a Desigualdade", ele fala na necessidade de "écarter tous les faits", e de partir de uma hipótese "semblable à ceux qui font tous les jours nos physiciens sur la formation du monde". (13) Compreende-se, tambem, por que o "Contrato Social" se abre com um ataque violento contra Grócio, acusado de recorrer frequentemente ao fato para explicar o Direito. Invocando uma passagem do marquês d'Argenson, Rousseau diz que esse é “o método mais favoravel aos tiranos", e que é por isso que o

(12) Vide em meu livro Formação da Politica Burgueza, São Paulo, 1934, o capitulo" “A religião da natureza e a anti-história".

(13) Cfr. nota 4 supra. Não entendo por que se costuma citar a referida passagem dos "Discursos" suprimindo-se a referência às hipóteses cosmológicas, tão densa de significado. 
direito público não passa, geralmente, de "l'histoire des anciens abus". (14)

Como se vê, o apriorismo de Rousseau, a abstração dos dados históricos, e a sua preferência por argumentos conjeturais baseados em elementos intuitivamente alcançados, tudo é apenas o caso particular e, digo mesmo, exponencial de uma atitude generalizada do espirito na França do sec. XVIII: no século anti-histórico por excelência ele fez "tabula rasa" da história social, transformando a velha idéia do "contrato social" em uma hipótese explicativa da ordem humana, análoga às concebidas pelos físicos para a explicação da ordem cósmica.

A prova mais convincente de que a forma cultural do século das luzes era favoravel à idéia de fundar a ciência política sôbre uma hipótese nos é dada pelos "Comentários sôbre as leis inglezas" de W. Blackstone, obra reconhecidamente eclética e que, talvez, pelo seu ecletismo, clareza e moderação, tão poderosa e larga influência exerceu nos primórdios do constitucionalismo europeu e americano.

Pois bem, Blackstone, que rejeita a formação histórica da sociedade mediante um contrato, sente a necessidade de aceilá-lo como um pressuposto "segundo a natureza e a razão":

"Si bem que a origem das sociedades não provenha formalmente de convenções de individuos determinados pela necessidade e pelo medo, é, contudo, o sentimento de sua fraqueza e de sua imperfeição que mantém os homens em sociedade, que lhes demonstra a necessidade dessa união e que é, por conseguinte, o fundamento sólido e natural, assim como o cimento da sociedade civil. E é isso que nós entendemos por contrato social pri-

(14) Cfr. Du Contrat Social, in Oeuvres Complètes, cit. I pg. 323. 
mitivo. Não existe, talvez, (sic) um só exemplo de ter sido esse contrato redigido na primeira instituição de um Estado: mas, segundo a natureza e a razão, êle é pressuposto no fato mesmo da associação. ." (15)

E com Kant, e, quasi ao mesmo tempo, com Frchte, que o contratualismo adquire um caráter especial, de inspiração rousseauniana, sem dúvida, mas com uma orientação original que se prolonga até aos nossos dias. (16)

Para melhor se aquilatar da inovação kantiana introduzida na doutrina contratualista, é necessário esclarecer,

(15) Blackstone, Commentaires sur les lois anglaises, trad. de Chompré, Paris, 1822, vol. I, pg. 71.

Os comentários de Blackstone foram publicados em 1765, três anos depois do "Contrato Social", embora a primeira preleção tenha sido dada em Oxford em outubro de 1858. E' mais provavel, entretanto, a influência de Rousseau sôbre o comentarista britânico do que a reciproca.

E' interessante notar que, já no prefácio dos Discursos sôbre a Desigualdade, Jean Jacques se refere ao estado de natureza como "un état qui n'existe pas, qui n'a peut-être (sic) existé, qui probablement n'éxistera jamais". Tambem no capitulo VI do "Contrato Social" Rousseau emprega ainda a forma dubitativa relativamente às cláusulas do Contrato: "Bien qu'elles n'aient peut-être (sic) jamais été formellement ennoncées, elles sont partout les mêmes, partout tacitement admises et reconnues..."

(16) Diz Jellinek (op. cit. pg. 417-419), que já em 1793, quasi quatro anos antes da "Doutrina do Direito" de KANT, J. G. Fichte publicára uma obra juvenil, reclamando não só uma interpretação mais exata do contratualismo de Rousseau, como tambem acentuando a sua natureza exclusivamente racional. $\mathrm{Na}$ realidade, porém, KANT expõe o seu pensamento, e com maior clareza do que na "Doutrina do Direito", exatamente em 1793, como veremos a seguir.

Sôbre as relações entre KANT e RousSEAu, vejam-se, entre outros, Fourllée, L'idée moderne du Droit, Paris, 1909, pg. 28 e segs. e V. Delbos, La Philosophie pratique de Kant, Paris, 1926, pg. 115 e segs. Janet, Histoire de la Science Politique dans ses rapports avec la Morale, 5.a ed., Paris, Alcan, t. II, pgs. 584 e segs. e 610 e segs.. Segundo Delbos, "conviria talvez mais a Rousseau do que a Hume a atribuição famosa de ter acordado KANT de seu sono dogmático" (loc. cit.). 
primeiro, a posição do filósofo em face da Escola do Direito Natural.

Nada me parece tão falho como colocar, sem maior exame, o filósofo das três críticas entre os continuadores do Jusnaturalismo, isto é, na Escola do Direito Natural fundada por Grócio ou Altúsio. De fato, se KANT nos dominios da filosofia jurídica não foi tão grande inovador como o foi na Lógica e na Etica, não é menos certo que a sua mudança de atitude em face do problema do conhecimento implicou em uma orientação de fecundos resultados, não só no plano da especulação filosófica, como na tela da Ciência Positiva do Direito, como se pode ver, por exemplo, nas obras de um Hugo e de um Thibaut (17).

Circunscritos que fiquemos, porém, à analise da doutrina jurídica de KanT, deve ser entendida em seus devidos termos a afirmação generalizada sôbre a reduzida inovação por ele feita nos domínios de nossa ciência.

"Na Filosofia do Direito, KaNT não foi um grande inovador", assevera entre outros DEL Vecchio: "limitou-se tão somente a aperfeiçoar, a depurar e a dar fórma mais clara, ao antigo processo da Escola do Direito Natural, corrigindo

(17) A poderosa influência do kantismo (note-se que me refiro às conclusões da filosofia crítica, e não à obra especial dedicada ao Direito) nos trabalhos de Hugo e de Thibaut é fato hoje perfeitamente esclarecido. Aliás, quando Hugo, no seu Tratado de direito natural como filosofia do direito positivo, reclamou uma nova metodologia para o estudo do Direito, aplicando os princípios da crítica kantiana, Fries, com muito acêrto, notou que a sua atitude era "de um kantismo mais consequente do que o do próprio KaNT", o qual, em verdade, não se mantivera "consequente" no estudo do Direito. (Cfr. Renato Treves, Il problema dell esperienza giuridica e la filosofia dell immanenza di G. Schuppe, Milão, 1938, pg. 97 e segs., e Solari, Filosofia del Diritto Privato, t. II, (Storicismo e Diritto Privato), Turim, 1940 , pgs. 15 e segs. De Thibaut não se póde dizer que haja sido "kantista" im ganz ähnlichen Sinne wie Hugo, como afirma LANDSBERG, mas é inegável que o seu jusnaturalismo sofreu forte correção em virtude de elementos do kantismo e das exigências do método histórico. (Cfr. Solari, op. cit., pg. 29 e segs.). A opinião corrente que vê em Thrbaut apenas um discipulo de Samuel Puffendorf, como faz, par exemplo, Alexandre Correia (A Concepção Histórica do Direito, São Paulo, 1934) não dá ao grande adversario de Savigny o exato lugar que lhe compete. 
o seu método de um modo rigoroso. Esta Escola havia afirmado, certamente, um princípio exato, a saber, que a base do Direito está no homem; porém, havia dado - pelo menos aparentemente - um significado histórico àquilo que era só um princípio racional; havia representado como processo empírico o que era unicamente um processo ideológico" (.. .) "Kant, na Filosofia do Direito, tem o mérito de haver desfeito a confusão entre o histórico e o racional, afirmando o valor puramente ideal (regulador) dos princípios do Direito Natural." (.. ) "Costuma-se designar essa correção de método, dizendo-se que com KANT acaba a Escola do Direito Natural (Naturrecht) e começa a do Direito Racional (Vernunftrecht). O Direito natural torna-se Direito de razão". (18).

Ora, basta ler atentamente as palavras acima para se concluir que não foi tão pequena a inovação de KANT na doutrina jurídica, abstração feita daquela que, como já dissemos, resultou da aplicação das conclusões do criticismo ao estudo do mundo do Direito por parte de "kantistas mais consequentes", antigos e contemporâneos. Parece-me que só essa distinção entre $o$ histórico $e$ o racional, essa atribuição de um valor puramente regulador aos preceitos do Direito Natural, bastou para marcar uma orientação de profundo significado, sendo pois justo assinalá-lo dizendo que Kant deu início à teoria do Direito Racional, que não se confunde com o Jusnaturalismo.

São, por esse motivo, de uma admiravel precisão estas palavras de Solari:

"Identificando o direito natural com o direito racional (Vernunftrecht) KANT se distinguia nitidamente dos jusnaturalistas, os quais, se eram racionalistas no método (ratio cognoscendi), assim não podiam ser considerados quanto ao princípio (principium cognoscendi) do qual deriva-

(18) Del Vecchio, Filosofia del Derecho, trad. de Recisens SICHES, t. II, pgs. 150-151. 
ram o Direito. Este era chamado Direito Natural por ser originado da natureza humana empiricamente considerada; mas tambem quando - na construção do mundo jurídico - partiam, não do sentido, mas da razão, esta era entendida em um significado psicológico e não lógico. Segundo KANT, a ordem jurídica não resulta do homem como ser vivo, mas é uma construção "a priori" da razão pura." (19).

Pois bem, essa mudança de atitude teve como resultado imediato a separação da concepção contratualista, não só de todo dado histórico - o que já havia sido realizado por JEAN JACQUes RousSEAU - mas tambem de todo elemento psicológico. O contratualismo de KANT desenvolve-se, de fato, exclusivamente no plano lógico, adquirindo uma expressão formal, sem nenhuma referibilidade à realidade concreta, histórica ou psicológica.

Neste ponto, julgo oportuno transcrever, aqui, as considerações feitas por Del Vecchio, nas suas claras "Lições de Filosofia do Direito", não só porque fixam bem a posição de KANT, como ainda porque, de certa fórma, reconhecem, mais do que nos ensáios do mesmo autor acima lembrados, as diferenças entre a doutrina do filósofo germânico e a de Rousseau :

"Em Filosofia, Rousseau não foi um técnico, mas sim um romântico. No seu desprêzo pelas sutilezas escolásticas e pelo tecnicismo dos filósofos profissionais, falou mais sob o influxo dos sentimentos do que por reflexão sistemática. Por esse motivo, cái, às vezes, em contradições aparentes, por não ter chegado a formular, com todo o rigor, a sua doutrina. O mérito dessa formulação

(19) Solarr, Individualismo e Diritto Privato, cit. pg. 210. (O grifo é nosso). 
precisa cabe a KANT. Efetivamente, lendo RorsSEAU, podemos ter, talvez, a impressão de nos encontrarmos ante uma narração mitológica, porquanto, na realidade, os homens jamais se uniram mediante um contrato expresso, e a sociedade é, especialmente em suas origens, independente de toda livre escolha. Rousseav, porém, quer apenas exprimir um princípio de avaliação (valoração - valutazione), isto é, que em todo Estado se deve pressupor o consentimento e o acôrdo livre de seus componentes. $E$ isto que Kant explica claramente, suprimindo todo equívoco quando diz que o Estado deve ser (não que foi) constituido segundo a idéia de um contrato social". (20).

Melhor será, entretanto, dizer que KANT dá pura expressão racional e lógica a um pressuposto que para RocsSEAU ainda tem base de ordem psicológica.

Roussead, aliás, não podia conceber algo de racional em si, separado do real, pois, consoante precisa observação de HöfFDing, "é tão somente com Kant que se chega à compreensão crítica da diferença que existe entre um ponto de vista ou idéia diretora e uma realidade dogmática, cuja existência seja pressuposta". (21).

Posta no plano lógico, a idéia do contrato adquire na doutrina de KANT um valor absoluto: não vale em virtude e em razão do consentimento dos obrigados, (o que seria dar um fundamento empírico à vida do Direito), mas vale: exclusivamente por si, por ser a expressão do supremo imperativo de conduta.

A sociedade, não podendo subsistir sem "o acôrdo da vontade de cada um com a vontade de todos segundo uma lei geral de liberdade", deve, necessariamente, ser concebida como se tivesse resultado do consentimento de todos,

(20) Del Vecchio, Filosofia del Derecho, cit., pgs. 163-164.

(21) Cfr. Höffding, op. cit., pg. 111 e seg. 
quando, de fato, esse imperativo da razão prática é superior às vontades individuais $e$ independente delas.

"Acôrdo é contrato, observa Farias Brito. Trata-se, pois, no fundo da idéia do contrato social. Mas em Kant esta idéia se transforma, porque o acôrdo não é estabelecido propriamente por livre consentimento, não resulta de um contrato, mas ao contrário tem o seu fundamento na organização mesma do espirito. Quer dizer: há uma lei que impõe o acôrdo das vontades na comunhão social. Esta lei é um princípio a priori nas mesmas condições que a lei de causalidade: é uma lei transcendental, um imperativo categórico; e como tal não é aceito de convenção, mas imposto de necessidade". (22).

A vista dessas palavras do pensador pátrio, póde parecer, entretanto, que o contratualismo de KANT esteja apenas implícito em sua doutrina, só resultando da interpretação de seus escritos, quando, na realidade, se trata de um contratualismo expresso, que o autor tem o cuidado de fixar de maneira clara e precisa, como elemento essencial que é de sua teoria do Direito e do Estado.

"Contrato social" e "estado natural" são dois conceitos fundamentais na concepção jurídico-política de KANT, cuja definição de Direito é, aliás, de cunho eminentemente pactista, eis que o considera um conjunto de condições mediante as quais o arbítrio de cada um póde se acordar com o de todos segundo uma lei geral de liberdade.

A idéia de "estado de natureza" alia-se, por outro lado, na doutrina kantista, à de "comunidade originária de terras e de bens" (communio possessionis originaria), a qual, tanto como a primeira, não apresenta, no dizer do próprio KANT, senão uma realidade juridicamente prática, sem se confundir com a de comunidade primitiva, méra invenção destituida de valor normativo.

Essa noção de "communio possessionis originaria", indispensavel à compreensão do direito privado de KANT, não

(22) F. BRiro, A verdade como regra das açôes, pgs. 106-107. 
é - para empregarmos as palavras mesmas do filósofo em seus "Metaphysische Anfangsgründe der Rechtslehre" - um conceito empírico, nem dependé de condições de tempo, como o conceito imaginário e indemonstravel de uma "communio primaeva”, que é uma invenção (23) : trata-se, ao contrário, de um conceito racional prático (ein praktischer Vernunftbegriff) que contém a priori o princípio mediante o qual tão somente é dado ao homem servir-se de seu logar sôbre a terra segundo as leis do Direito, porquanto a possibilidade da aquisição originária do sólo e, por conseguinte, todo o sistema da propriedade privada, assenta na idéia de uma "communio possessionis originaria", no sentido de que, inicialmente, nenhuma vontade estava excluida da posse de algo. (24).

Ora, assim como a idéia de comunhão originária de posse justifica a propriedade privada e é um dos elementos condicionantes do Direito Privado kantista, da mesma forma a idéia de contrato social condiciona - sempre como um conceito racional prático, e não empírico — o seu sistema de Direito Público.

Com efeito, o "contrato social" é para KANT o fundamento da vida social e política. "O ato, escreve ele, mediante o qual o povo se constitue por si mesmo em Estado, ou melhor, a simples idéia desse ato, mediante a qual uni-

(23) Preferimos dizer "invenção", porque KANT - como se lê à pg. 53 do vol. VII da magnífica edição das "Immanuel Kants Werke" de CASSIRER, (Berlim, 1922) - emprega o termo Erdichtung em sua acepção mais genérica. A tradução de BARNI (Cfr. "Elements Métaphysiques de la Doctrine du Droit, Paris, 1856, pg. 74) não se nos afigura, nesse ponto, de todo fiel. Ficção, no sentido de algo pressuposto por exigência da razão prática, seria antes a "communio possessionis originaria".

(24) Cfr. Kant, Metaphysische Anfangsgründe der Rechtslehre, cit. $\S \S 6$ e 13 . Como nota RuxsSEN, dessa idéia decorre que o direito de propriedade não póde senão resultar da vontade coletiva de todos os individuos, e que não existem direitos privados originários ("Kant", Paris, 1929). Rousseau, ligando o aparecimento da propriedade ao trabalho e à agricultura, dá mostra de compreensão mais realista do problema. Cifr. Discours. 
camente se pode conceber a legitimidade desse Estado, è o contrato originário, pelo qual todos (omnes et singuli) no povo renunciam à sua liberdade exterior para retomá-la, logo a seguir, como membros de uma comunidade, isto é, do povo enquanto Estado (universi)". (25)

Como se vê, não o ato, mas a simples idéia do ato (eigentlich aber nur die Idee desselben) da realização de um contrato constitue o princípio da organização políticojurídica.

Estamos, não ha dúvida, em face de uma pura idéia de razão, que, no dizer do filósofo não contém nenhum elemento empírico. E' por esse motivo que ele afasta de sua teoria contratual toda e qualquer conjetura sôbre a formação histórica das sociedades, afirmando ser inutil procurar as origens históricas desse mecanismo, por ser impossivel remontar ao ponto de partida da sociedade civil, (Der Geschichtsurkunde dieses Mechanismus nachzuspüren, ist vergeblich, d. i. man kann zum Zeitpunkt des Anfangs der bürgerlichen Gesellschaft nicht herauslangen). (26).

Esses trechos dos "Elementos Metafísicos da Doutrina do Direito" bastam para demonstrar o carater puramente racional que o contrato social assume na doutrina kantista, mas, pelo menos quanto ao objeto deste estudo, penso que assiste razão a Friedrich PAULSEN quando assevera que a teoria do Estado e do Direito das Gentes de Kant, mais do que na obra acima citada, deve ser buscada em seus ensáios anteriores. (27)

Na matéria de que tratamos, é de decisiva importância um estudo que o mestre de Könisgberg escreveu em 1793, intitulado "Sôbre o dito (Gemeinspruch): Isto pode ser certo em teoria mas não vale nada na prática".

Na segunda parte dessa monografia, dedicada à crítica

(25) KANT, Metaphysische Anfangsgründe der Rechtslehre, cit., $\S 47$.

(26) . KaNT, op. cit., § 52.

(27) Cfr. Paulsen, Kant, trad. ital. de Bernardo Sesta, Ed. Sandron, pg. 322. 
de Hobbes, Kant esclarece, de maneira cristalina, a espécie de seu contratualismo, nos seguintes termos:

"Eis aí um contrato originário, sôbre o qual tão somente se poderá fundar entre os homens uma constituição civil e, por conseguinte, inteiramente jurídica, instituindo-se uma entidade comum. Esse contrato especial, denominado contractus originarius ou pactum sociale, como coalisão de todas as vontades particulares e privadas de um povo em vista de uma vontade comum e pública, no escopo de uma legislação puramente jurídica (zum Behuf einer blosz rechtlichen Gesetzgebung), não precisa, porém, ser absolutamente pressuposto como um fato (ist keinesweges als ein Faktum vorauszusetzen notig), o que, aliás, seria impossivel, como se, antes de mais nada, fosse necessário provar, à luz da História, que um povo, em cujos direitos e obrigações nós entramos como posteridade, haja realmente concluido outrora um ato dessa natureza, dele nos deixando, oralmente ou por escrito, uma notícia ou documento que nos permita julgarmo-nos ligados a uma constituição já existente.

"Essa não é, pois, senão uma pura idéia de razão (eine blosze Idee der Vernunft), mas uma idéia que possui a sua realidade prática incontestavel: realidade no sentido de que ela obriga todo legislador a ditar as suas leis de maneira tal que elas poderiam ter sido emanadas da vontade coletiva do povo todo; e ainda no sentido de que cada súdito, enquanto quiser ser cidadão, ha de se considerar como se (als ob) tivesse concorrido com os demais para a formação dessa vontade. Porque essa é a pedra de toque da legitimidade de todas as leis públicas". (28)

(28) KANT, Uber den Gemeinspruch: Das mag in der Theorie richtig sein, taugt aber nicht für die Praxis, in "I. Kants Werke", cit. vol. VI, pgs. 380-81. Cfr. ainda, à pg. 386 do mesmo volume, como KANT, contestando uma afirmação de DANTON, reafirma que a idéia de contrato social deve ser apreciada "nicht als Faktum (. .) sondern nur als Vernunftprinzip der Beurteilung aller öffentlichen rechtlichen Verfassung überhaupt".

Como já dissemos, no mesmo ano de 1793, Fichte publicou uma obra juvenil, Considerações sôbre a Revolução Francesa, na qual ele explica que não se deve entender o Contrato Social em um sentido 
Depois dessas considerações bem pouco ha a acrescentar: o "contrato social" é uma pura idéia de razão, um princípio racional de ordem prática, uma pedra de toque (Probierstein), uma unidade de medida para a justa apreciação da legitimidade dos Govêrnos, da conformidade ou adequação da ordem jurídica positiva à ordem social justa.

O carater deontológico do contrato social resulta assim provado com evidência, pois não é apenas uma medida semelhante às empregadas no plano físico, mas uma medida que implica em um imperativo de conduta, em uma ordenação da razão prática. E, nesse sentido, aliás, que tanto DeL Vecchio como Höffding comparam, igualmente, a idéia de contrato social de Rousseau a uma "unidade de medida", como vimos na nota 11 supra, não sendo demais notar que, em significativa coincidência, tambem CASSIRER considerar o Sozialkontrakt de Kant "ein Masztab" (29).

A diferença entre a concepção de Rousseau e a de Kant está, por conseguinte, não no significado deontológico do contrato, que é comum, mas na maneira em que ambos os pensadores situam esse valor de aferição.

Na concepção kantista a distinção entre "ser" e "deverser" é sempre precisa, como duas ordens irredutiveis: o conceito de "contrato social" é posto tão somente no plano do dever ser, do Sollen, sem nenhuma referência a dados empíricos do mundo do Sein. Como bem observa JANET, é. de algum modo, a forma a priori, sem a qual não podemos

histórico, e que Rousseau mesmo não entendeu de outra forma: esse contrato, escreve o grande filósofo i.dealista, não é senão uma idéia, considerada como tipo e como regra que as sociedades devem seguir; não é de fato mas de direito que as sociedades civis repousam sôbre um contrato. Cfr. Fichte - Considerações sur la Révolution Française - trad. de BarnI, Paris, 1860, pg. 100.

(29) Cfr. Cassiren, Kants Leben und Lehre, cit. pg. 329. Se insisto sôbre esse ponto é porque a idéia de buscar algo de racionalmente posto para a aferição da justiça de um ordenamento legal ficou sendo como que um "leit-motiv" das doutrinas de inspiração kantista. Basta lembrar, por exemplo, a preocupação de STAMmLer na determinação dos elementos de uma "comunidade pura", para padrão da legitimidade ou valoração de uma ordem jurídica positiva. Cfr. Miguel Reale, Fundamentos do Direito, cit. pgs. 142 e segs. 
pensar um Estado, qualquer que seja a sua origem empírica $(30)$.

Já em Rousseau essa separação radical entre o que é e o que deve ser, entre a realidade e o ideal - que se harmoniza com todo o formalismo filosófico de KANT - não a encontramos. Rousseau seria incapaz, por temperamento, de conceber algo, destinado a explicar a vida, sem referência aos valores concretos da vida; de apresentar como pura forma lógica o que é destinado a falar ao sentimento e a preparar a ação.

Na sua imaginação criadora o que deve ser de certa forma já é. Ele antecipa o ideal, injetando-o na realidade, que adquire a aparência e a fôrça de um mito. Ele não diz como Kant: "eis o que a Razão Prática ordena, cumprí;" mas sim: "eis o que seria a realidade se a ordenação da razão fosse cumprida".

Moralista, Kant vê antes a norma. Doutrinador político, Rousseau vê antes a reação psicológica em face da norma. É por isso que o filósofo alemão plana alto no mundo das puras idéias de razão, ao passo que o genebrino as anima com o seu sentimento, preferindo a sedução de uma realidade idealizada (em que "ser" e "dever ser" se fundem) ao traçado lógico-geométrico das condições da legitimidade jurídica.

Rousseau não tem um sistema em que deva enquadrar lógicamente a sua concepção do Direito. Quando ele concebe o contrato como uma hipótese não se preocupa com a necessidade de afirmar a seu valor "a priori", como condição de sua universalidade, mas prefere ver, com os olhos da imaginação, a realidade ideal, em uma antecipação rica de fôrça poética.

Ele sabe que a sociedade "deve ser" constituida "como se" resultasse de um contrato, mas, para tornar mais palpavel e sedutor o imperativo da razão, imagina a sociedade

(30) JANEt, Histoire de la Science Politique, cit., vol. II, pg. 611. 
"como se" o contrato ideal já fosse realidade, descrevendo os seus momentos e as suas cláusulas.

No fundo, Rousseau talvez seja mais coerente do que KANT. Este pretende ter chegado ao princípio do "contrato social" sem referibilidade a elementos empíricos, partindo tão só de imperativos racionais, quando, na realidade, a sua concepção contratualista está assente em uma consideração especial da natureza humana.

A análise da natureza humana é, na doutrina de RousSEAU, um ponto de partida expresso; na de KanT é um elemento implícito, subentendido, da qual êle pretende, em vão, subtrair-se, tendo em vista a sua tese de que só é universal o que é "a priori" e só é "a priori" o que é formal.

Analisando-se, porém, a obra de Kant, vê-se que a sua concepção do homem é a concepção mesma de Rousseau, mais racional talvez, e sem devaneios, mas sempre a concepção dominante no século XVIII.

Não será demais dizer algo sôbre tão importante materia.

Tanto Kant como Rousseau são otimistas em relação ao homem. Não se pense, porém, que ambos só enxergam no homem expressões de santidade, como parece resultar do forçado perfil que Maritain nos deu do autor do "Emilio". Ao contrário, ambos reconhecem que o homem é capaz de fazer o mal, de empregar a violência e de agir com cega paixão, mas - e é aqui que reside o seu otimismo - se isso acontece e constitue um fato, não é dito que não se possa reformar a vida social, sôbre outras bases de mútuo respeito, segundo os ditames da bôa razão.

Não se esqueça, em verdade - e este ponto tem sido muito facilmente olvidado - que na obra de Roussau se contrapõem dois contratos sociais, um falso e o outro verdadeiro: um é o contrato leonino ou histórico, o pseudo-contrato da desigualdade e do arbítrio, se é que se pode denominar contrato o que é méro resultado da fôrça; o outro é 
o contrato ideal ou racional, que é o da liberdade e do consenso mútuo. A História nos apresenta uma sociedade fundada na violência e na opressão, na desigualdade dos bens e das dignidades; a Razão nos aponta uma sociedade fundada na Justiça e no respeito humano. O que se deve fazer é proclamar o primado da Razão sôbre a História, sobrepôr o contrato social racional ao contrato social leonino que se diz maliciosamente implícito nos desmandos dos mais fortes e na subserviência dos débeis.

$O$ século XVIII, com toda a sua incompreensão pela História - e na França, nem mesmo Montes ouieu chegou a constituir uma clara exceção nessa falta de senso histórico, da qual, fóra da França, apenas Burke realista e o genial Vico se libertaram - está todo aí nesse contraste, nessa oposição, nesse choque entre a realidade e o ideal, norteando o contratualismo da época revolucionária.

Quando se afirma, pois, que Rousseau prégou a volta ao estado de natureza se comete um êrro por omissão, perdendo-se de vista o real significado de suas duas obras construtivas, o "Emilio" e o "Contrato Social".

Digo que o "Contrato Social é uma obra construtiva, porque penso ser impossivel compreendê-la sem referência à que foi escrita em 1755, ou seja, 7 anos antes, os "Discours sur l'Origine et les Fondements de l'Inégalité parmi les hommes", que é um trabalho de crítica, e, até certo ponto, de demolição.

Nos “Discursos sôbre a Desigualdade", o pensador genebrino não pretende, como já foi observado, reconstituir uma época remota da história humana. A sua é uma concepção hipotética, de base eminentemente psicológica e que visa responder a esta pergunta: "Dados os instintos naturais do homem, as suas tendências e inclinações, ou seja, dada a natureza humana, quais as prováveis causas da formação da sociedade atual, baseada na desigualdade?" Sob a aparência de uma reconstrução histórica, temos uma sondagem, uma penetração nos refolhos da alma humana. $\mathrm{E}$ por isso que Rousseau, quasi ao terminar os Discours tem o cuidado 
de reafirmar o carater eminentemente conjetural de sua obra: "J'ai tâché d'exposer l'origine et le progrés de l'inégalité, l'établissement et l'abus des sociétés politiques, autant que ces choses peuvent se déduire de la nature de l'homme par les seules lumiéres de la raison" (31).

À luz da razão, Rousseau compreende o homem no estado de natureza como um ser substancialmente bom, gozando da mais ampla liberdade, sem o mal das desigualdades e privilégios. Entretanto, essa vida livre é tambem uma vida sem garantias, quasi instintiva, de sorte que os homens são levados naturalmente a sair dela para o desenvolvimento de suas faculdades e o progresso de seu espírito. Pois bem, o que a história nos mostra não é o estabelecimento de uma constituição que, mantendo a liberdade primitiva, creasse condições de garantia ao desenvolvimento do espírito humano: ao contrário, a organização civil se fez em vantagem de poucos, estabelecendo-se um acôrdo leonino entre os mais fortes e os mais fracos. A conclusão dos Discours é exatamente esta: as desigualdades existentes não resultam da natureza humana, mas de um desvio das inclinações naturais, de um abandono das tendências inatas, pelo predomínio da fôrça e do arbítrio.

Em verdade, é o próprio Rousseau quem nos dá, em claro resumo, a conclusão de seu trabalho: "Il suit de cet exposé, escreve ele, que l'inegalité, étant presque nulle dans l'état de nature, tire sa force et son accroissement du développement de nos facultés et des progrés de l'esprit humain, et devient enfin stable et légitime par l'établissement de la propriété et des lois" (32).

Ora, estabelecida essa conclusão e admitida a bondade fundamental do homem, era natural e lógico que ao espirito de Rousseau se apresentasse a segunda questão, relativa às condições de uma ordem social justa entre homens livres. 0 "Contrato Social" é a resposta a essa segunda pergunta.

(31) Rousseau, Discours, ed. cit., vol. I, pg. 53.

(32) Rousseau, Discours, ed. cit., vol. I, pg. 53. 
E' por esses motivos todos que não vejo contradição, nem antagonismo entre os Discours e o Contrat: se na primeira obra se demonstra, à luz da razão, que a sociedade atual, baseada no privilégio e na desigualdade, é fruto de um desenvolvimento falso das faculdades humanas, na segunda se demonstra como deve ser racionalmente organizada a sociedade; se a primeira é a explicação de um contrato, ou melhor, de um pseudo contrato que consagrou, pela malícia e pela fôrça, os abusos dos mais fortes, a segunda obra é a exposição do contrato verdadeiro e autêntico.

Em última análise, o que Rousseau pretende não é absolutamente a volta ao estado de natureza, porquanto, se a ordem social atual é injusta, ela não deixa, entretanto, de apresentar vantagens evidentes quanto à garantia recíproca e ao aperfeiçoamento das faculdades do espírito humano: o que importa é conservar o que ha de bom na sociedade civil, mas sem sacrifício da liberdade natural.

Dess'arte, o "Contrato Social" é, logícamente, a obra complementar dos "Discursos sôbre a Desigualdade", não existindo entre esses dois trabalhos nem a separação que Berolzheimer aponta, nem a contradição que WaHL assinala (33).

O juizo que Kant faz dos homens não é diverso do de Rousseau. T'ambem para o filósofo do idealismo transcendental o ser humano é substancialmente bom, capaz de progredir no sentido do que é ditado pela razão, desde que sejam afastados os obstáculos que se opõem externamente ao expontâneo desenvolvimento natural (34).

(33) No sentido de uma íntima relação entre as duas obras se pronuncia Solari (op. cit., vol. I, pg. 117) e, em linhas gerais, Höffding (op. cit., pg. 97). Para Del Vecchio não existe senão uma relação lógica e formal entre os dois trabalhos, ao passo que Berolzheimer claramente os separa. Cfr. Berolzheimer, Sistema di Filosofia del Diritto e dell'Economia, trad. de D'Eufemia, Napoles.

(34) "Kant, escreve Delbos, participa da confiança de RousSEAU na bondade primitiva da natureza humana". 0 ilustre professor francês lembra, a propósito, estas significativas palavras de KANT: "Dizem na medicina que o médico é o servidor da natureza; 
Admitindo embora a bondade natural do homem, KANT acentua, porém, de tal fórma a atuação das inclinações inferiores e reconhece com tanto realismo a existência de lutas entre indivíduos e grupos que um crítico sereno e comedido como PAulsen chega ao extremo de compará-lo a HobBes.

"Kant - escreve Paulsen, expondo-lhe a doutrina sôbre a origem do Estado - segue aquí, nos pontos essenciais, o pensamento de HoBBes, não obstante se intitular "Contra HoBbes" o trabalho sôbre o Direito do Estado, que faz parte da coletânea "Sôbre o dito comum etc". O Estado é feito resultar essencialmente dos impulsos egoistas e antisociais đa natureza humana: se não aparece a expressão bellum omnium contra omnes, existe, porém, o pensamento a ela correspondente. Aliás, tambem KaNT diz uma vez de modo expresso: "o dito de HobBes status hominum est bellum omnium in omnes tem um único defeito; deveria ser transformado neste outro: est status belli" (35).

Paulsen adianta mesmo que não existe divergência substancial entre a doutrina de KANT e a de HoBBEs, visto como tambem o filósofo britânico dava ao contrato social um méro valor hipotético.

Não resta dúvida - e sôbre este ponto muitos são os de opinião idêntica - que HobBes, tanto como Rousseau e KaNT, nunca pensou na realidade histórica da origem contratual da convivência humana, mas daí a concluir pela identidade fundamental das doutrinas vái distância longa e intransponivel.

A primeira divergência que existe entre o contratualismo de Hobbes e o de Rousseau e Kant decorre da concepção diferente que eles têm da natureza humana. Para os pensadores da Alemanha e de Genebra, o homem é um sêr essencialmente bom, que, por desvio de suas tendências natu-

mas a mesma máxima vale na moral. Afastai sómente o mal que vem de fóra: a natureza tomará por si mesma a direção melhor". Cfr. Delbos, op. cit. pgs. 120 e seg..

(35) Paulsen, op. cit. pg. 326. 
rais, vive em um estado de desigualdade e de guerra, sendo, porém, capaz de se libertar dessa ordem irracional para assentar a vida social sôbre novas bases postas pelas exigências da razão. Para HobBes, ao contrário, o homem seria incapaz de pôr um termo à luta violenta de uns contra os outros, sem que o próprio interesse individual exigisse o aparecimento de um poder mais alto, capaz de impôr o equilibrio e garantir a cada um a sua esfera particular de ação, e isto por não admitir a bondade natural dos homens.

Na doutrina de HobBes a constituição da sociedade civil resulta, por assim dizer, da sublimação da fôrça individual em uma fôrça super-individual que é representada pelo monarca absoluto. Este não intervém, como parte, na estipulação das clausulas contratuais: resulta, ao contrário, do acôrdo das vontades individuais, como uma "solução personificada", como único recurso bastante para compôr os antagonismos e garantir a todos ordem e estabilidade. Não sendo possivel, a seu ver, uma organização social puramente racional, dada a natureza humana, HoBBes transforma o problema da realização de uma "ordem justa" no problema, mais prático e utilitário, da realização de uma "ordem garantida" (36).

Outro ponto em que Kant se afasta de HoBBes resulta da idéia do fim que os homens devem naturalmente se propôr, pois, enquanto o primeiro assenta o contrato sôbre a idéia de felicidadie, o segundo o fundamenta na idéia de liberdade.

São de admiravel precisão as seguintes considerações de Delbos em sua clássica monografia sôbre a filosofia prática de KaNT:

(36) Como tem sido observado por abalizados intérpretes do pensamento hobbesiano, não deixa HobBes de ser racionalista, a seu modo. Note-se que é a razão que, afinal, se impõe aos imperativos do interesse, quando estes se refreiam para alcançar uma garantia mútua. Sôbre estes pontos, cfr. Mrguel Reale, Formação da Política Burgueza, cit. pgs. 168 e segs., e Teoria do Direito e do.Estado, cit., pgs. 199 e segs. 
“Em materia de direito político Kant é de opinião que a tese da contradição entre a teoria e a prática foi enunciada por HoBBes, quando este, no De Cive, (VII, § 14) sustentou que o chefe de Estado não assume, pelo contrato, obrigação alguma em relação ao povo e que, por mais que ele faça o que entender, não poderá jamais cometer injustiças contra os cidadãos. Essa proposição tomada em sua generalidade é aterradora. Porque, pelo fato do súdito ofendido não ter nenhum direito de coerção sôbre o soberano, ela estabelece que perante este aquele não possue direito algum. Essa confusão HoBbes a teria evitado se tivesse bem compreendido os princípios do direito político. $O$ contrato, que constitue a sociedade civil, não repousa sôbre a idéia do fim que os homens naturalmente se propõem, ou seja, sôbre a idéia de felicidade, mas sôbre a idéia de liberdade concebida nas relações exteriores dos homens entre si" (37).

Da diversidade do fim proposto resulta, claramente, uma diferença na natureza do contrato, que, na doutrina kantista tem um valor puramente formal e lógico, e na de HoBbes um fundamento empírico.

Quanto à passagem do "estado de natureza" para o de "sociedade civil" ainda é notavel a diferença entre o escritor do Leviathan e o da Crítica da Razão Pura.

Neste ponto se parecendo mais com Rousseau, HobBes explica a passagem do estado de natureza para o estado jurídico da sociedade mediante o exame das provaveis exigências sentidas por todos os indivíduos, fazendo resultar a convivência civil da pressão das necessidades reveladas pela experiência. Para KANT, ao contrário, como é sutilmente notado pelo já citado Delbos, a ordem jurídica não é a con-

(37) Deubos, op. cit., pgs. 692 e seg. 
sequência empirica das necessidades da vida humana, mas se apresenta "como uma obrigação que resulta analiticamente da noção mesma do direito".

Por outras palavras, segundo KANT a ordem jurídica se constitue porque entre os indivíduos existe sempre a potencialidade da luta: é esse o sentido real da afirmação "est status belli", que tanto impressionou a Paulsen. A ordem jurídica surge, como um imperativo de razão, porquanto o estado de natureza é um estado de justiça simplesmente negativa, no qual, se um direito fosse controvertido, não existiria nem a lei determinada, nem o juiz competente para pronunciar a sentença justa, de sorte que, sob uma aparência de justiça, a violência responderia à violência.

O contratò social é, em suma, para Kant mais do que para qualquer outro pensador, a condição sem a qual o homem não poderia realizar o seu fim último. $E^{\prime}$ isso que o filósofo do idealismo transcendental já havia afirmado, em 1790, em sua obra fundamental sôbre a crítica do juizo, antecipando as conclusões de toda a sua doutrina do Direito e do Estado:

"A condição formal pela qual tão somente a natureza pode alcançar o seu fim último é uma constituição das relações dos homens entre si, na qual um poder legal, em um todo chamado sociedade civil, se oponha à lesão das liberdades respectivas em luta umas contra as outras, pois sómente na sociedade as disposições naturais podem se desenvolver até ao mais alto gráu possivel" (38).

$\mathrm{E}^{\prime}$ por esses motivos todos que podemos dizer que o contratualismo alcança a sua expressão máxima, toda a expansão de sua fôrça lógica, na doutrina de Emanuel Kant, o mais profundo e criador interprete da cultura individualista.

(38) Vide todo o parágrafo 86 da Kritik der Urteilskraft. 